\title{
The level of endogenous DNA damage in lymphocytes isolated from blood is associated with the fluctuation of $17 \beta$-estradiol concentration in the follicular phase of healthy young women ${ }^{*}$
}

\author{
Maria Kapiszewska ${ }^{\bowtie}$, Malgorzata Kalemba, Aneta Grzesiak and Kinga Kocemba \\ Department of General Biochemistry, Faculty of Biotechnology, Jagiellonian University, Krakow, Poland; \\ 凶e-mail: mkapisz@if.uj.edu.pl
}

Received: 05 April, 2005; revised: 19 May, 2005; accepted: 03 June, 2005

availale on-line: 20 June, 2005

\begin{abstract}
The aim of this study was to evaluate whether the differences in plasma $17 \beta$-estradiol concentration in early and late follicular phases of the menstrual cycle can affect the level of endogenous DNA damage in lymphocytes assessed by comet assay, and whether the extent of this damage in the follicular phase is associated with the genotype of catechol-O-methyltransferase (COMT). The level of DNA damage was positively correlated with $17 \beta$-estradiol concentration only in the late follicular phase. Subjects with the COMT L/L homozygous mutated variant revealed more DNA damage as compared to individuals with the COMT wild-type and heterozygous $(\mathrm{H} / \mathrm{L}+\mathrm{HH})$ genotype.
\end{abstract}

Keywords: $17 \beta$-estradiol, endogenous DNA damage, catechol-O-methyltransferase (COMT), comet assay

The risk of hormone-related cancer, in particular breast cancer, seems to depend on the prolonged exposure to $17 \beta$-estradiol and its hydroxylated metabolites, i.e. catechol estrogens, which are easily auto-oxidized to semiquinones and subsequently to quinones (Huang et al., 1999; Thompson \& Ambrosone, 2000). Since both compounds are electrophiles, they can covalently bind to nucleophilic groups in DNA, forming stable and unstable DNA adducts (Peluso et al., 2000; Raftogianis et al., 2000). Moreover, the redox cycling reaction between semiquinones and $O$-quinone radicals generate superoxide and hydroxyl radicals which can cause oxidative cleavage of the phosphate-sugar backbone, as well as oxidation of purine/pyrimidine residues of DNA (Liehr, 1997; 2000). The extent of this damage is evaluated mainly by HPLC or by comet assay (Singh et al., 1988; Olinski et al., 1998; Tice et al., 2000; Collins et al., 2002). The single strand breaks in DNA and alkali-labile sites (ALS), such as apurynic/apyrimidinic sites, can be detected as the proportion of DNA in the comet tail during alkaline microgel electrophoresis. This method has been widely used to study the DNA modifications resulting from metabolic changes (Abrahamse et al., 1999), caused by environmental toxins or drug administration (Abd-Allah et al., 1999; Puhakka et al., 2002) and some nutritional deficiencies (Giovannelli et al., 2002; Szete et al., 2002; White et al., 2002; Kapiszewska et al., 2005a). It was shown that the comet assay used to study single/double strand breaks and oxidative modifications in the DNA bases was sensitive enough to detect also alterations in the antioxidant status in the body induced by nutritional supplements or vitamins (Betancourt et al., 1995; Anderson et al., 1997; Anderson, 2001; Beani, 2001). The endogenous DNA damage analyzed in lymphocytes is very often used as a biomarker of the oxidative stress in the human body (Porrini et al., 2002; Szeto et al., 2002; Wolf et al., 2002; Mayne, 2003). Constant exposure of lymphocytes to substances transported by circulation make them very useful and reliable as a diagnostic tool. Taking all of the above into account, it is reasonable to expect that if circulating estrogens and their metabolites enhance free radical production, then their detrimental effect can be manifested in DNA modification also in lymphocytes. We showed recently that

Presented at the XXXII Winter School, 3-7 March 2005, Zakopane, Poland.

Abbreviations: ALS, alkali-labile sites in DNA; COMT, catechol-O-methyltransferase; EFPh, early follicular phase; FPh, follicular phase; LFPh, late follicular phase; ROS, reactive oxygen species; TDC, percentage of DNA in the comet tail. 
the protective ability of plant extracts against oxidative DNA damage induced by hydrogen peroxide in lymphocytes depends on the concentration of $17 \beta$-estradiol circulating in the blood and on the catecholO-methyltransferase (COMT) phenotype (Kapiszewska et al., 2005). The COMT enzyme is involved in detoxification through methylation of catechol estrogens inhibiting the redox cycling, thereby decreasing reactive oxygen species formation (Matsui et al., 2000). The enzyme activity is determined, in part, by a common genetic polymorphism. The COMT enzyme activity is 3-4-fold lower in the variant with a single nucleotide mutation $\left(\mathrm{L}^{*}\right)$, causing a Val108Met substitution, as compared to the homozygous wildtype $(\mathrm{H} / \mathrm{H})$ (Lavigne et al., 1997). Such a correlation between the COMT genotype and the activity of the enzyme was found in different human tissues (Levitt et al., 1982; Casey \& MacDonald, 1983; Nissinen, 1985; Nissinen et al., 1988; Li et al., 1989; Matsui et al., 2000). The availability of methyl group donors, which in turn indirectly depends on the folate and vitamin B12 status in the body, also influences the efficiency of the detoxification (Fenech, 2001; Goodman et al., 2001; Kapiszewska et al., 2005).

The results presented here verify our earlier observation that endogenous alkali-labile DNA damage is strictly related to $17 \beta$-estradiol concentration in the follicular phase (FPh), and that lymphocyte DNA susceptibility is associated with the COMT genotype.

\section{MATERIALS AND METHODS}

Chemicals. Agarose for electrophoresis, grade ultra pure, and agarose normal and low melting point ultra pure, medium (RPMI 1640), serum (FBS), phosphate-buffered saline (PBS) and antibiotics were purchased from Gibco BRL (UK); Agarose Top Vision, dNTPs and Pfu DNA polymerase were from Fermentas (Lithuania), while NlaIII restriction enzyme was from Q-Biogen; DMSO (dimethyl sulfoxide), ethidium bromide, propidium iodide, Tris were from Sigma (USA); DNA Extraction Kit was from A\&A (Poland); EDTA, Triton X100 was supplied by MP Biomedicals; oligonucleotide primers were synthesized by Institute of Biochemistry and Biophysics, PAS (Warsaw, Poland); salts and hydroxides were from POCh (Poland).

Study design. The female volunteers composed a very homogeneous group in terms of age, weight, lifestyle and smoking habits. They had not taken oral contraceptives or other hormonal medications for six months before the study began. They were not taking any other medications and had no history of recent infections. Samples were collected from subjects during a single normal menstrual cycle at two specific time points: in the early follicular phase (days 1-3 post-onset of menses) and during the late follicular phase (days 13-15 post-onset of menses), designated in the text, Figures and Tables as EFPh and LFPh, respectively. The study protocol was reviewed and approved by the Ethics Committee of the Jagiellonian University Medical College.

Sample preparation and analysis. The concentrations of $17 \beta$-estradiol and folate in plasma were determined by radioimmunoassay using commercially available kits manufactured by Orion (Finland) at the Department of Clinical Biochemistry, Jagiellonian University Hospital (Krakow, Poland).

Peripheral blood lymphocytes. Peripheral blood lymphocytes were isolated using the Histopaque technique according to the manufacturer's instructions (Sigma) and were frozen at $-80^{\circ} \mathrm{C}$ at 4 $\times 10^{6}$ cells $/ \mathrm{ml}$ in "freezing medium" consisting of $65 \%$ RPMI-1640, 25\% fetal bovine serum and 10\% DMSO.

Comet assay. The single cell gel electrophoresis (comet assay) procedure was described in details in our previous study (Kapiszewska et al., 2005a). Briefly, the lymphocytes were embedded in $0.5 \%$ low melting point agarose (LMPA) and spread on microscopic slides pre-coated with $100 \mu \mathrm{l}$ of $0.5 \%$ normal melting point agarose. The slides were immersed in cold lysing solution $(2.5 \mathrm{M} \mathrm{NaCl}, 100 \mathrm{mM}$ EDTA, 10 $\mathrm{mM}$ Tris, $\mathrm{pH} 10,10 \%$ DMSO, and $1 \%$ Triton $\mathrm{X}-100$ ) for $1 \mathrm{~h}$ and washed with Tris buffer. For visualization of DNA damage, observations were made using a $10 \times$ objective (the final magnification was $\times 200$ ) on an epifluorescence microscope (Olympus IX-50) equipped with appropriate filters. The microscope was linked to a computer through a CCD camera (i.CAM-hrM; sensor SONY ICX). The Comet Plus image analysis system from Theta System Gmbh (Germany) was used for the quantification of DNA damage.

The percentage of DNA in the tail (designated in the Figures as TDC) was automatically calculated. At least two slides per one subject, with 50 randomly selected cells per slide, were analyzed.

COMT genotype analysis. The COMT genotype was determined by polymerase chain reactionrestriction fragment length polymorphism (PCRRFLP) using the NlaIII restriction enzyme. Details of the method are described elsewhere (Kapiszewska et al., 2005).

Statistical analyses. Data obtained from the comet assay (\% tail DNA, "TDC") were subjected to a logarithmic transformation because of heterogeneity of variance. The correlation between DNA damage and 17ß-estradiol concentration in the plasma was examined with the linear regression analysis using the least-squares method. The results were presented as a scatter plot with a linear regression line fitted to the data with a $95 \%$ confidence interval. A correlation coefficient $(r)$ and $P$ values were calcu- 
lated. The association between the COMT polymorphism and the ALS, calculated using mean values from measurements taken in EFPh and LFPh, was analyzed by non-parametric Mann-Whitney $U$-test and presented as a Box Whisker plot.

\section{RESULTS AND DISCUSSION}

The comet assay is mainly used to evaluate genotoxic hazard of drugs, chemicals or environmental exposure. Its sensitivity, however, allows evaluation also of DNA modification due to less severe agents, such as physical exercise, diabetes or different UV exposure and nutrition in various seasons (Hartmann et al., 1994; Sardas et al., 2001; Dusinska et al., 2002). This means that an enhancement in the DNA comet migration can also be observed as a result of physiological processes and not only due to genotoxic exposure. These breaks cannot be distinguished from those which reflect the genotoxic effect. Moreover, they may represent the transient error-free repair sites.

Using the alkaline version of comet assay we assessed whether the variation in the circulating level of $17 \beta$-estradiol in the follicular phase of menstrual cycle can affect the extent of endogenous DNA damage in lymphocytes isolated from healthy women donors.

As data obtained in human studies can be biased by confounding factors, the donors $(n=16)$ were chosen for our study in such a way as to create a very homogeneous group in terms of age (32 years \pm 3 ), weight $(61.4 \mathrm{~kg} \pm 9.6)$, life-style and smoking habits (non-smokers). The concentrations of $17 \beta$-estradiol and folate in the plasma were analyzed by radioimmunoassay. The mean values are shown in Table 1 . The mean values of $17 \beta$-estradiol concentration in the plasma in EFPh and LFPh were significantly different $(P=0.001)$. The differences in folate concentrations in EFPh and LFPh were not statistically significant.

The analyzed level of ALS was significantly positively correlated with the estradiol concentration only in LFPh, where the concentration of $17 \beta$-estradiol was in the range from 36 to $368 \mathrm{pg} / \mathrm{ml}(r=0.53$; $P=0.03$ ) (Fig. 1). No such dependence was observed

Table 1. Mean values of $17 \beta$-estradiol and folate concentration in plasma during a single menstrual cycle in early and late follicular phases (days 1-3 or 13-15 post-onset menses, respectively).

\begin{tabular}{lccc}
\hline & $\begin{array}{l}\text { Early folli- } \\
\text { cular phase } \\
(\text { EFPh })\end{array}$ & $\begin{array}{l}\text { Late follicu- } \\
\text { lar phase } \\
(\mathrm{LFPh})\end{array}$ & $P$-value \\
\hline $\begin{array}{l}\text { 17 } \beta \text {-Estradiol } \\
(\mathrm{pg} / \mathrm{ml})\end{array}$ & $30.8 \pm 25.5$ & $154.8 \pm 105.0$ & 0.001 \\
Folate $(\mathrm{ng} / \mathrm{ml})$ & $9.6 \pm 6.2$ & $11.6 \pm 5.7$ & 0.3 \\
\hline
\end{tabular}

in EFPh, where mean $17 \beta$-estradiol concentration was $30.8 \mathrm{pg} / \mathrm{ml}$ (Table 1). The extent of ALS was not correlated with the averaged EFPh + LFPh concentration of $17 \beta$-estradiol in the plasma calculated for each individual $(P=0.09)$.

There is a background level of DNA damage in normally functioning cells due to metabolic activities, including reactive oxygen species (ROS) production. This damage is not detrimental until an imbalance between the pro-oxidant and anti-oxidant factors occurs. DNA strand breaks can be caused directly by the attack of hydroxyl radicals formed during the oxidation of catechol estrogens. Thus, if more catechol estrogens are produced in the late follicular phase, as compared to the early phase, more alkalilabile sites in DNA can be induced. This hypothesis was confirmed by our results.

In individuals with more efficient detoxification/methylation of catechol estrogens less damage can be expected, as the methylation not only prevents the redox cycling between semiquinones and quinines, which decreases ROS production, but also forms methyl ether metabolites with a strong antioxidant activity.

More ALS was found in FPh in lymphocytes isolated from blood of women with the COMT L/L genotype, as compared to the heterozygous variant $(\mathrm{H} / \mathrm{L})$ and wild-type genotype $(\mathrm{H} / \mathrm{H})$ grouped together $(P=0.05)$ (Fig. 2$)$. The mean values of $17 \beta$ estradiol concentration in both groups were similar, that is the difference between them was statistically insignificant $(P=0.8)$. Since the folate concentration in plasma in both groups was not significantly different $(9.7 \mathrm{ng} / \mathrm{ml} \pm 1.04$ and $10.9 \mathrm{ng} / \mathrm{ml} \pm 4.9$ for COMT $\mathrm{L} / \mathrm{L}$ and COMT $(\mathrm{H} / \mathrm{L}+\mathrm{H} / \mathrm{H})$, respectively), the finding implicates that more DNA damage in the COMT $\mathrm{L} / \mathrm{L}$ group can result from insufficient detoxification of catechol estrogens due to lower COMT L/L activ-

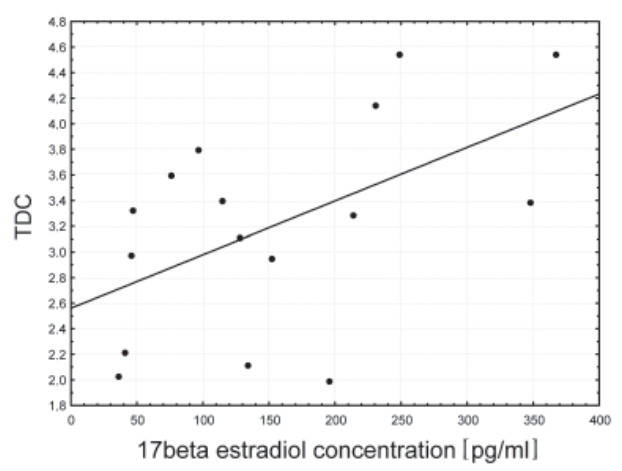

Figure 1. Correlation between $17 \beta$-estradiol concentration in plasma during the late follicular phase (LFPh) in lymphocytes isolated from blood and alkali-labile DNA damage.

The DNA damage was analyzed by comet assay and expressed as the percentage of DNA in the tail (TDC). The correlation $(r=0.53$ and $P=0.03)$ was evaluated by linear regression analysis using the least-squares method. 


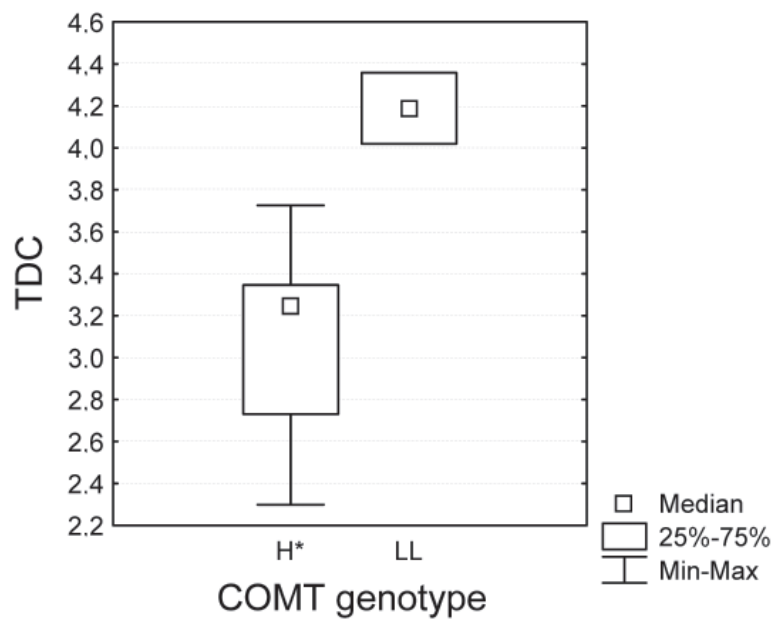

Figure 2. Box and Whisker plots showing relationship between the level of endogenous alkali-labile DNA damage (ALS) in lymphocytes isolated in follicular phase from women grouped according to the COMT genotype.

The first group $(\mathrm{n}=13)$ combines wild-type homozygote $\mathrm{H} / \mathrm{H}$ and heterozygote with mutated allele $\mathrm{H} / \mathrm{L}\left(\mathrm{H}^{*}\right.$ in the Figure) the second group $(n=3)$ comprised mutated homozygotes LL. The level of ALS was expressed as the percentage of DNA in the tail (TDC). The TDC was calculated using mean values from measurements taken in the follicular phase (EFPh and LFPh), $P=0.05$ (non-parametric Mann-Whitney U-test)

ity. Since the number of subjects in the $\mathrm{L} / \mathrm{L}$ group $(n=3)$ was much lower than in the group with the combined genotypes $(n=13)$, the conclusion has to be drawn carefully until the results are confirmed with more subjects.

The observed variation in endogenous DNA lesions during the follicular cycle indicates that evaluation of genotoxicity of drugs and environmental toxins should also take into account the influence of physiological processes which take place in the studied subjects during the investigation. For example, the activity of the immune system can also be responsible for a correlation between $17 \beta$-estradiol concentration and DNA lesions. It has been postulated that estrogen in the follicular phase contributes to the development of an immune response classified as Th1, which is characterized by the production of cytokines, such as IFN- $\gamma$, IL-2, and TNF- $\beta$. Furthermore, concentration of TNF- $\alpha$ fluctuates over the menstrual cycle and significantly increases during the late follicular phase (Brannstrom et al., 1999). These inflammatory mediators are generated depending on estrogen concentration, leading to DNA damage, including strand breakage (Cutolo et al., 2002; 2004; Lang, 2004; Rosales et al., 2004; Salem, 2004). Also, at the time of ovulation, the number of neutrophils increases 8-fold; that may influence local production of cytokines, including IL- 1 , TNF- $\alpha$ and IL-8 (Brannstrom et al., 1993). Thus, endogenous oxidative DNA damage in lymphocytes from the late follicular phase, as compared with the early phase, may not necessarily only reflect the harmful effect of $17 \beta$-estradiol and its metabolites but can be also a sign of the activation of Th1 cells.

\section{CONCLUSION}

Association between endogenous DNA damage in lymphocytes and $17 \beta$-estradiol concentration in circulation can partially explain the inter-individual variation of the extent of endogenous DNA damage in lymphocytes from healthy donors, as reported in many studies (Buschfort et al., 1997; Martin et al., 2000; Gonzalez et al., 2002). Also, involvement of polymorphism of genes responsible for the detoxifying pathways in the induction of endogenous DNA damage should not be ignored.

\section{Acknowledgements}

This project was supported by a grant from the State Committee for Scientific Research, Poland, project No. 3 P05E 01625.

\section{REFERENCES}

Abd-Allah GA, el-Fayoumi RI, Smith MJ, Heckmann RA, O'Neill KL (1999) Mutat Res 446: 181-188.

Abrahamse SL, Pool-Zobel BL, Rechkemmer G (1999) Carcinogenesis 20: 629-634.

Anderson D (2001) Mutat Res 480-481: 337-347.

Anderson D, Phillips BJ, Yu TW, Edwards AJ, Ayesh R, Butterworth KR (1997) Environ Mol Mutagen 30: 161174.

Beani JC (2001) Bull Acad Natl Med 185: 1507-1525.

Betancourt M, Ortiz R, Gonzalez C, Perez P, Cortes L, Rodriguez L, et al (1995) Mutat Res 331: 65-77.

Brannstrom M, Mayrhofer G, Robertson SA, (1993) Biol Reprod 48: 277-286.

Buschfort C, Muller MR, Seeber S, Rajewsky MF, Thomale J (1997) Cancer Res 57: 651-658.

Casey ML, MacDonald PC (1983) Am J Obstet Gynecol 145: $453-457$

Collins AR, Dusinska M, Gedik CM, Stetina R (1996) Environ Health Perspect 104: Suppl 3, 465-469.

Cutolo M, Seriolo B, Villaggio B, Pizzorni C, Craviotto C, Sulli A (2002) Ann NY Acad Sci 966: 131-142.

Cutolo M, Sulli A, Capellino S, Villaggio B, Montagna P, Seriolo B, et al (2004) Lupus 13: 635-638.

Dusinska M, Vallova B, Ursinyova M, Hladikova V, Smolkova B, Wsolova L, Raslova K, Collins AR (2002) Food Chem Toxicol 40: 1119-1123.

Fenech M (2001) Mutat Res 475: 57-67.

Giovannelli L, Saieva C, Masala G, Testa G, Salvini S, Pitozzi V, et al (2002) Carcinogenesis 23: 1483-1489.

Gonzalez C, Najera O, Cortes E, Toledo G, Lopez L, Betancourt M, et al (2002) Teratog Carcinog Mutagen 22: $147-158$.

Goodman JE, Lavigne JA, Wu K, Helzlsouer KJ, Strickland PT, Selhub J, Yager JD (2001) Carcinogenesis 22: 16611665. 
Hartmann A, Plappert U, Raddatz K, Grunert-Fuchs M, Speit G (1994) Mutagenesis 9: 269-272.

Huang CS, Chern HD, Chang KJ, Cheng CW, Hsu SM, Shen CY (1999) Cancer Res 59: 4870-4875.

Kapiszewska M, Zajac G, Kalemba M, Soltys E (2005) I Pharmac Physiol 59: Suppl 1, 183-197.

Kapiszewska M, Kalemba M, Wojciech U, Milewicz T (2005a) J Nutr Biochemistry (in press).

Lang TJ (2004) Estrogen as an immunomodulator. Clin Immunol 113: 224-230.

Lavigne JA, Helzlsouer KJ, Huang HY, Strickland PT, Bell DA, Selmin O, et al (1997) Cancer Res 57: 5493-5497.

Levitt M, Hunter C, Baron M (1982) Neuropsychobiology 8: 276-279.

Li SA, Purdy RH, Li JJ (1989) Carcinogenesis 10: 63-67.

Liehr JG (1997) Eur J Cancer Prev 6: 3-10.

Liehr JG (2000) Endoc Rev 21: 40-54.

Martin FL, Cole KJ, Harvey D, Weaver G, Williams JA Millar BC, et al (2000) Carcinogenesis 21: 799-804.

Matsui A, Ikeda T, Enomoto K, Hosoda K, Nakashima H, Omae K, Watanabe M, Hibi T, Kitajima M (2000) Cancer Lett 151: 87-95.

Mayne ST (2003) J Nutr 133: Suppl 3: 933S-940S.

Nissinen E (1985) Anal Biochem 144: 247-522.

Nissinen E, Tuominen R, Perhoniemi V, Kaakkola S (1988) Life Sci 42: 2609-2614.

Olinski R, Jaruga P, Zastawny TH (1998) Acta Biochim Polon 45: 561-572.
Peluso M, Airoldi L, Magagnotti C, Fiorini L, Munnia A, Hautefeuille A, Malaveille C, Vineis P (2000) Carcinogenesis 21: 183-187.

Porrini M, Riso P, Oriani G (2002) Eur J Nutr 41: 95-100.

Puhakka A, Ollikainen T, Soini Y, Kahlos K, Saily M, Koistinen P, et al (2002) Mutat Res 514: 7-17.

Raftogianis R, Creveling C, Weinshilboum R, Weisz J (2000) J Natl Cancer Inst Monogr 27: 113-124.

Rosales AL, Cunningham JM, Bone AJ, Green IC, Green MH (2004) Free Radic Res 38: 665-674.

Salem ML (2004) Curr Drug Targets Inflamm Allergy 3: 97104.

Sardas S, Yilmaz M, Oztok U, Cakir N, Karakaya AE (2001) Mutat Res 490: 123-129.

Singh NP, McCoy MT, Tice RR, Schneider EL (1988) Exp Cell Res 175: 184-191.

Szeto YT, Collins AR, Benzie IF (2002) Mutat Res 500: 3138

Thompson PA, Ambrosone C (2000) J Natl Cancer Inst Monogr 27: 125-134.

Tice RR, Agurell E, Anderson D, Burlinson B, Hartmann A, Kobayashi H, Miyamae Y, Rojas E, Ryu JC, Sasaki YF (2000) Environ Mol Mutagen 35: 206-221.

White KL, Chalmers DM, Martin IG, Everett SM, Neville PM, Naylor G (2002) Br J Nutr 88: 265-271.

Wolf FI, Torsello A, Covacci V, Fasanella S, Montanari M, Boninsegna A, et al. (2002) Exp Gerontol 37: 647-656. 